\title{
Discussion on Construction of Network Teaching Platform Resources
}

\author{
Keying Jiao \\ Zhumadian Vocational and Technical College He Nan 463000
}

\author{
Keywords: Network teaching; Resource construction; Status quo; Significance
}

\begin{abstract}
With the development of era and the innovation of the society, people pay more and more attention to the reform and innovation of the education. The network teaching platform as the new teaching mode of the university. Through analyzing the construction of network teaching platform in the colleges, understand the current construction of purpose and the status quo, and understand the composition of network teaching resources. The advent of the Internet era, let network technology has been known and used widely, different from the traditional mode of education, the construction of network teaching platform is to adapt to the development of the times. However, there are still many problems in the construction of the current network teaching platform and need to continuously improve the construction in order to better of college teaching.
\end{abstract}

\section{Introduction}

Digital teaching resources are an important guarantee to improve the quality of education and teaching. It is the core to realize the modernization of higher education and construct of a new educational model. But how to effectively use the resources properly in the teaching process, how to adhere to sustainable resources construction and application, is the focus that we set up the cyber source platform to realize the digital, is the main work of the university informatization. In order to promote the education informationization construction application of work, efforts to enhance teaching informationization level, change the teaching idea, improve teaching methods and quality, and create a new highlight of school education teaching. The network teaching platform is not only the embodiment of the advanced computer science and technology, but also conforms to the needs of education development rule now. It can provide a high-tech means for distance education, strengthen the communication between teachers and students, teaching resources can spresd through the network to improve the quality of teaching.

\section{The Status Quo of Network Teaching Platform Teaching Resources in Universities}

Network teaching platform is a Web based management and teaching platform, it has a variety of teaching resources, students can take advantage of teaching resources of autonomous learning, and online communication, to achieve one-on-one high efficiency of teaching. It is the basic platform which supports a variety of teaching, colleges in our country are building network teaching platform, and realizing the construction popularization of teaching platform. Each college has its own network platform, and the main contents are: the production process, the three-dimensional material, describe the course syllabus, lesson plans, teaching arrangements, work online, discussion, curriculum, online examination, courseware, video, network teaching platform for testing and evaluation of various resources, through the sharing of teaching resources, to improve the utilization of educational resources for students. It's quick and convenient for students to use, and combined with their own request to choose curriculum resources, teaching resources management and dynamic accumulation of media resources, information resources, network teaching resources combination of curriculum resources are the prerequisites for the implementation of network teaching. The establishment of digital media resources library, the resource center and its management system, can support the dynamic accumulation and utilization of multimedia teaching resources. 


\section{The Significance of the Construction of Network Teaching Platform Teaching Resources}

Enrich Teaching Content and Form. In the traditional teaching, the teaching mode is spoon-fed, the teacher as the main body, the dominant position in the classroom, teaching contents and the degree of difficulty is decided by teachers, student's learning habits and methods are different, so the traditional teaching methods are limited, the lack of teachers led to students to learn outside the classroom has the certain difficulty. The construction of network teaching platform can be very good to break it, through the network teaching platform to transfer teaching resources, including teaching content, courseware, PPT, etc., to a certain extent also effectively reduce the stress of the teachers. Even if the teacher is away, students also could learn through the network teaching platform, without the restriction of time and place, students completely independent to arrangement learning according to the needs and interests of their own, so as to improve the students' learning efficiency.

The Student as the Main Body. Through the construction of network teaching platform, students can learn through the platform anytime and anywhere. The students take the main part in the study and have more learning autonomy. The construction of network teaching platform is a breakthrough of traditional teaching forms; the teaching tool is no longer just chalk and blackboard. The use of network platform, online education and related concepts will not only bring about changes in teaching methods, teachers, teaching strategies, teaching design, teaching design, teaching methods, teaching methods, but also the teaching of the role may change. The construction of network teaching platform, without the restrictions of time and place, there is a great deal of independent space, as long as there is the desire of learning can be realized. And adapt to different students, can watch the video on the network teaching platform by play faster or slower to adjust a course, so that different levels of students according to their basics and acceptance to control the video speed. As the video can be repeated play, so that the student who responded slowly and ashamed to ask questions can easily to watch. It is conducive to the improvement of student learning efficiency. Most of the network teaching platform has online communication, operation testing and other functions, to facilitate students to learn and independent assessment, the gaps found insufficient learning, fully embodies the autonomy.

The Innovation of Education Mode. By the impact of examination-oriented education, the traditional teaching model is just to deal with the two exams: Senior-High School Entrance Examination, College Entrance Examination. The teaching method is based on spoon-fed by teachers, so students in a passive position. The trend of current education development is the increasing of the number of students and lake of teachers. The lack of teachers reduce the efficiency of teaching in each college reduce the teaching efficiency. However the construction of network teaching platform will effectively alleviate the shortage of teachers, and students can use its teaching resources in autonomous learning, students change the role from passive to active so that to improve the efficiency of teaching.

\section{Network Teaching Platform Construction of Teaching Resources}

Strengthen the Network Technology Training for Teachers. Teachers should pay more attention to enhance the effectiveness of the network teaching platform, in the platform construction process to analyze the student's English learning situation fully, according to the actual needs of students to design and use of network teaching platform, to strengthen the information feedback of submitted homework to the student, to do well the use effect of tracking platform, so as to improve teaching efficiency. Colleges can be held on a regular basis for the training of teachers, including basic knowledge of network, the computer processing word, learn to collect all kinds of educational information and educational resources on the internet. Both to improve the ability of teaching level of teachers' information technology and application, to further enhance the effectiveness of classroom teaching, and the teaching quality of the school has played a positive role in promoting. The school will promote the application of information technology capabilities to a new level. Teachers to strengthen learning, change the traditional teaching concept and research, establish a 
new concept of resources, teaching, research and the concept of cooperation, and have a certain degree of information technology literacy, can use the computer and collect, integration, publishing a variety of education resources on the internet. It will continuously improve the ability of network teaching and research and practical results.

Strengthening the Construction of Professional Organizations. Each college on the construction of network teaching platform is still in the stage of development, various aspects are not mature, there are many problems need attention. To build a better platform for teaching network, we need to strengthen the division of labor in the professional sector. In view of the network teaching platform, the colleges need to set up a special organization department, combined with the current education and teaching technology, computer network technology, teachers and many aspects of the development of high quality network teaching platform. In the construction of network teaching platform teaching resources, colleges should emphasize the key specialties, and purchase or compile teaching resources according to the development of them. The network teaching platform construction must have the corresponding supervisory department, each college needs to establish the corresponding supervising and Directing Department, in order to discover the question which the feedback exists, promptly improves. The college should encourage the construction of the network teaching platform, plan the special teaching funds, and set up the corresponding network teaching platform construction funds according to the actual situation, make the platform carry out smoothly and improve the teaching efficiency.

Coordinate all aspects of Relations. In the university network teaching platform construction, in addition to the professional training of teachers and the construction of the professional sector, the most important to the coordination of all aspects of the relationship. Network teaching resources construction is a complex and cumbersome process, involving a number of departments, including Academic Departments, Network Centers, libraries, teachers, etc, if the division of labor is not clear, it is easy to produce contradictions, so it need to strengthen communication and cooperation between various departments, coordination of all aspects of the relationship, let the development of network teaching resources to build smoothly and improve teaching efficiency.

\section{Conclusion}

At present, the reform of education in China is guided by the informatization development program, combining regular teaching research with network teaching and researching, network as the platform, realizing routine teaching and research network, teaching and research management network, network teaching regularization, network management systematization, combining with modern network technology, more in line with the development needs of the times for the current education teaching form. The current network teaching platform as a new teaching model, more and more colleges attach importance to the construction of network teaching platform, network teaching platform is also gradually popularized and widely used, it's advanced computer science and technology level of expression, and suitable for the current education teaching form. Due to the breadth of the network teaching platform, students can learn through the network platform no matter when and where, students can according to their interests and needs choose the course content, different from the traditional study in the classroom, only listening to the teacher, the construction of network teaching platform is proving a platform for students to arrange their own learning time and place in the spare time. Network teaching platform is more prominent as the main body of the students, teachers are only secondary, through the network platform to achieve teachers and student's one-on-one teaching, but also improve student learning efficiency, network technology and education and teaching to improve teaching efficiency, combining network technology and the education teaching, improve teaching efficiency. The development of education informatization promotes the development of universities, building a complete curriculum system, strengthening the connotation construction of colleges; improve the teaching level of teachers. To improve the quality of education in schools through the sharing of curriculum resources is a new measure to promote the development of education of Ministry of Education Chinese. 


\section{References}

[1] Yang Jianjun, He Hengguang. The foundation and backbone of constructing the new online classroom and characteristic education [J]. China audio visual education, 2006 (10)

[2] Hao Zengming. On the construction of teaching resources in higher education [J]. modernization of education, 2003 (9): 57-58

[3] Zhao Haixia, Xie Shuxiao, and so on. The development path, strategic influence and rational thinking of higher education [J]. MOOC modern education technology, 2014, (7): 6-7

[4] Liu Qingtang, Wang Zhonghua, and. Design and development of online education resources [M]. Beijing: Peking University press, 2009:4-7

[5] Wu Weimin. Orientation and implementation strategy of network teaching platform [J]. Journal of distance education, 2003, (): 18-19

[6] Ren Ren. Deep thinking on the construction of network teaching resources [J]. distance education in China, 2003, (18): 26-29

[7] Wang Zhuli, leaves on the construction of teaching resources. Meihong campus network [J]. Chinese thinking of higher medical education, 2004, (2): 22-23 